\title{
PKM DESA GITIK DALAM PENINGKATAN PRODUKSI INDUSTRI RUMAH TANGGA TAHU
}

\author{
Shinta Setiadevi ${ }^{1}$, Dian Ridlo Pamuji ${ }^{2}$ \\ ${ }^{1}$ Staf Pengajar Program Studi Agribisnis Politeknik Negeri Banyuwangi \\ ${ }^{2}$ Staf Pengajar Program Studi Teknik Mesin Jurusan Teknik Mesin Politeknik Negeri Banyuwangi \\ ${ }^{1}$ Email: shinta.setiadevi@poliwangi.ac.id
}

Naskah diterima: 19 November 2018 ; Naskah disetujui: 31 Desember 2018

\begin{abstract}
Soybean is one of the Banyuwangi district food crops which has the potential to continue to be seeded besides rice, corn, peanuts, green beans, cassava, and sweet potatoes. Banyuwangi Regency was designated as one of the national soybean barns by the Ministry of Agriculture of the Republic of Indonesia since 2015 with an area of 100 hectares in Muncar District. The soybean varieties developed are New Superior Varieties (VUB). The productivity obtained eaches 3 tons per hectare beyond the national soybean productivity average if 1.5 tons per hectare. The most important part of soybeans is soybean seeds. One product produced by soybean seeds is tofu. Tofu is a staple food for the people of Indonesia, causing demand to continue to increase so IKM knows that it continues to strive to meet market needs. Banyuwangi Regency makes processed tofu as a typical snack called tahu walik. Tahu walik is one of the typical Banyuwangi snacks made from fried tofu which is reserved so that inside of the tofu is outside and filled with chicken dough. The majority of the people in Gitik Village, Rogojampi District have a business processing soybeans into white tofu products and household-scale fried tofu. The quality of the tofu produced still has high water content. The amount of tofu produced is still small, this is caused by the use of traditional tofu presses. The transition from traditional tofu presses to modern ones is expected to be able to improve the quality and quantity of products obtained.
\end{abstract}

Keywords: Banyuwangi, tofu, tofu presses

\section{PENDAHULUAN}

Kedelai merupakan salah satu komoditas tanaman pangan kabupaten Banyuwangi yang berpotensi untuk terus diunggulkan selain padi, jagung, kacang tanah, kacang hijau, ubi kayu, dan ubi jalar. Kabupaten Banyuwangi ditetapkan sebagai salah satu lumbung kedelai nasional oleh Kementerian Pertanian (Kementan) Republik Indonesia sejak pertengahan 2015 dengan luas lahan seluas 100 hektar di Kecamatan Muncar. Varietas kedelai yang dikembangkan adalah Varietas Unggul Baru (VUB). Produktvitas yang diperoleh mencapai 3 ton per hektar melampaui ratarata produktivitas kedelai nasional yaitu 1,5 ton per hektar.

Bagian kedelai yang paling penting adalah biji kedelai. Salah satu produk hasil pengolahan biji kedelai adalah tahu. Tahu merupakan makanan pokok masyarakat Indonesia, menyebabkan permintaan tahu terus meningkat sehingga IKM tahu terus berupaya untuk memenuhi kebutuhan pasar. Kabupaten Banyuwangi menjadikan olahan tahu sebagai jajanan khas yang disebut tahu walik. Tahu Walik merupakan salah satu jajanan khas Banyuwangi yang terbuat dari tahu goreng yang dibalik sehingga bagian dalam tahu berada di luar dan diisi oleh adonan ayam [1]. Tahu menjadi produk olahan yang dapat mempengaruhi roda perekonomian kabupaten Banyuwangi.

Perekonomian kabupaten Banyuwangi didukung oleh beberapa sektor diantaranya sektor perdagangan, sektor industri, sektor jasa. Sektor perdagangan merupakan sektor ekonomi yang masih paling banyak diminati oleh pelaku usaha di kabupaten Banyuwangi. Sektor perdagangan besar dan eceran mampu menyerap tenaga kerja mencapai 95.445 orang yang tersebar di Kecamatan Muncar, Srono, Genteng, Rogojampi, dan Banyuwangi. Salah satu desa di Kecamatan Rogojampi adalah Desa Gitik. Mayoritas masyarakat di Desa Gitik memiliki usaha pengolahan kedelai menjadi produk tahu putih dan tahu goreng. Salah satunya adalah Bapak Heri Purnomo. Proses produksi tahu Bapak Heri masih dilakukan secara manual menggunakan alat-alat tradisional turun-temurun 
[2]. Tujuan dari kegiatan ini adalah untuk membantu mitra pengusaha tahu dalam meningkatkan kualitas dan kualitas produksi.

\section{METODOLOGI}

Pembuatan dan pengujian alat pres dilakukan di Workshop Pengelasan, Program Studi Teknik Mesin Jurusan Teknik Mesin Politeknik Negeri Banyuwangi pada bulan Mei - November 2018. Prosedur kegiatan meliputi:

1. survei lokasi

2. pembuatan alat pres tahu

3. ujicoba dan aplikasi alat

4. penerapan alat

5. monitoring dan evaluasi kegiatan.

\section{HASIL DAN PEMBAHASAN}

\section{Hasil Survei Lokasi}

Survei lokasi bertujuan menemukan permasalahan yang dihadapi mitra dan berdiskusi menentukan metode pelaksanaan kegiatan untuk menyelesaikan permasalahan. Mitra memiliki peran untuk menjelaskan proses produksi tahu, kualitas dan kuantitas tahu yang dihasilkan, dan manajemen operasional kegiatan usaha yang dilakukan. Hasil survei ditunjukkan pada gambar 1 di bawah ini.

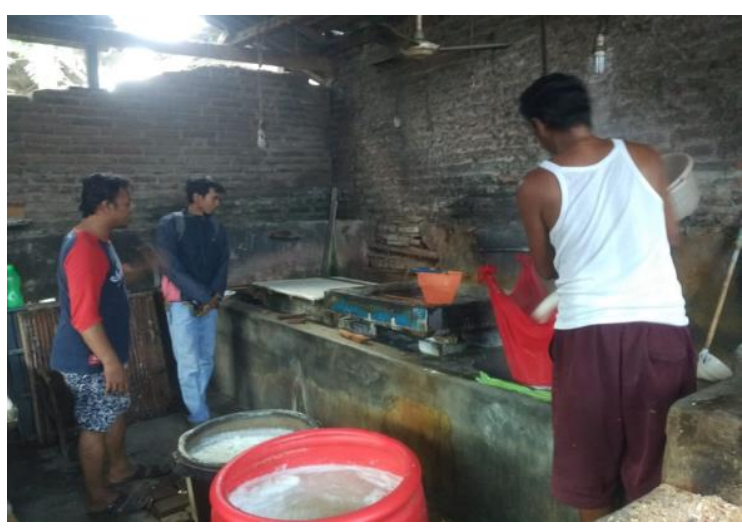

Gambar 1. Hasil survei lokasi

\section{Hasil Pembuatan Alat Pengepres Tahu}

Proses pembuatan alat pengepres tahu diawali dengan menentukan desain alat pengepres tahu yang mudah dioperasikan, selanjutnya membuat rancangan komponen-komponen berdasarkan desain yang telah ditetapkan sehingga alat yang dihasilkan aman dan memiliki waktu operasional yang lama. Komponen yang dibuat terlebih dahulu adalah loyang sebagai tempat pengepres tahu, kemudian rangka alat pengepres tahu. Alat pengepres tahu ditunjukkan pada gambar $2 \mathrm{di}$ bawah ini.

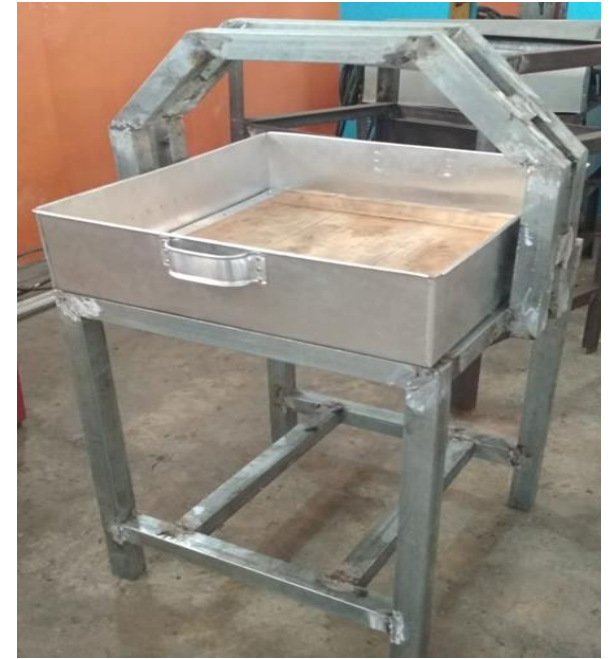

Gambar 2. Desain Alat Pengepres Tahu

Jika pemasangan semua komponen dan pengecatan alat telah dilakukan, maka alat pres dapat diujicoba dandioperasikan dengan baik. Spesifikasi alat pres tahu sebagai berikut:

1. Loyang $=60 \times 60 \times 15 \mathrm{~cm}$

2. Tinggi kaki-kaki $=80 \mathrm{~cm}$

3. Tiang penyangga $=60 \times 60 \mathrm{~cm}$

4. Jarak ulir dengan pres $=20 \mathrm{~cm}$

5. Panjang poros ulir $=50 \mathrm{~cm}$

\section{Hasil Ujicoba dan Aplikasi Alat}

Setelah alat pengepres tahu selesai dibuat. Langkah selanjutnya adalah ujicoba alat sebelum dilakukan transfer teknologi kepada mitra hingga diperoleh hasil ujicoba yang sesuai dengan spesifikasi. Tahapan selanjutnya yaitu aplikasi alat dengan menyerahkan alat pengepres tahu dan memberikan pelatihan kepada mitra dan para pekerjanya. Pelatihan tersebut berupa cara pengoperasian dan perawatan alat pengepres tahu secara intensif.

\section{Hasil Penerapan Alat}

Alat pengepresan tahu yang telah diujicoba selanjutnya digunakan untuk kegiatan produksi tahu di lokasi produksi mitra. Alat pengepres tahu yang dipilih untuk diterapkan kepada mitra pengabdian kepada masyarakat ini adalah alat bantu menggunakan sistem pres manual dengan ulir yang bertujuan memberi tekanan pada campuran kedelai yang dituang didalam loyang alat pres tersebut. Konsep alat bantu pres ini memiliki keunggulan yaitu menekan campuran kedelai secara maksimal hingga menyisakan ampas kedelai yang tidak terpakai, namun kelemahan yang dimiliki alat bantu pres ini yaitu waktu yang dibutuhkan pekerja untuk memutar ulir kebawah (menutup loyang) dan keatas loyang (membuka loyang) cukup lama [3]. 


\section{Hasil Monitoring dan Evaluasi Kegiatan}

Indikator keberhasilan kegiatan ini adalah minat dan kemampuan mitra untuk dapat menggunakan hasil transfer teknologi tepat guna untuk meningkatkan kualitas, kuantitas, dan daya saing produk. Monitoring dan evaluasi kegiatan dilakukan setelah mitra memperoleh manfaat penggunaan alat pengepres tahu yang dihasilkan. Evaluasi yang diperoleh yaitu:

1. Mitra hanya memiliki alat pengepres tahu manual menggunakan bambu dan pemberat timba berjumlah 1 buah, dengan adanya tambahan alat pres tahu ini, mitra dapat meningkatkan produktivitas tahu untuk memenuhi kebutuhan konsumen. Selama ini waktu yang dibutuhkan pekerja untuk membuat tahu putih (mengurangi kadar air campuran kedelai) sekitar 10 menit dengan alat manual. Jika pekerja menggunakan alat pres tahu ini, maka waktu yang dibutuhkan menjadi lebih cepat sekitar 3-5 menit.

2. Kualitas tahu yang diproduksi dapat lebih baik karena tempat pengepres campuran kedelai menjadi tahu putih berbentuk loyang alumunium yang menggunakan pemberat yang lebih baik dan mudah untuk dibersihkan.

3. Pekerja mitra berjumlah 2 (dua) orang. Alat pengepres tahu yang digunakan oleh mitra dapat mempercepat pekerjaan pekerja dan menurunkan kelelahan kerja yang dirasakan oleh pekerja.

4. Jika waktu produksi tahu menjadi lebih cepat dan rasa lelah pekerja berkurang, maka kesejahteraan pekerja pada mitra ini dapat bertambah [4].

5. Kegiatan ini menghasilkan diskusi lebih lanjut antara mitra dengan tim pengabdi tentang perkembangan alat-alat produksi tahu yang lebih ergonomis untuk memudahkan pekerja dalam proses produksi sehingga meningkatkan produktivitas pada kegiatan pengabdian kepada masyarakat selanjutnya.

\section{KESIMPULAN}

Kesimpulan yang diperoleh dari kegiatan pengabdian ini adalah alat-alat yang digunakan oleh mitra kegiatan masih bersifat tradisional, salah satunya adalah alat pengepres tahu. Kegiatan pengabdian yang dilakukan bertujuan:
1. Meningkatkan produktivitas tahu sehingga mitra sebagai produsen dapat memenuhi kebutuhan konsumen.

2. Meningkatkan kualitas tahu yang diproduksi.

3. Meningkatkan kesejahteraan pekerja.

4. Menjalin hubungan kerjasama dengan mitra untuk kegiatan pengabdian kepada masyarakat selanjutnya.

\section{SARAN}

Perlu adanya pengembangan alat pengepres tahu yang lebih modern untuk memudahkan proses produksi mitra.

\section{DAFTAR PUSTAKA}

[1] Pemerintah Kabupaten Banyuwangi. 2018. Tamasya Rasa Bumi Blambangan (Kuliner Khas Banyuwangi Warisan Resep Leluhur dari Generasi ke Generasi). Banyuwangi.

[2] Kabupaten Banyuwangi. Panen Kedelai 3 Ton/Hektar, Banyuwangi Jadi Percontohan Nasional.

https://www.banyuwangikab.go.id/beritadaerah/panen-kedelai-3-tonhektarbanyuwangi-jadi-percontohannasional.html. Diakses tanggal 9 Mei 2018.

[3] Mulyana, J, Santosa, H, Prasetya, W. 2013. Perancangan Alat Penyaringan dalam Proses Pembuatan Tahu. JITI. 12(1): 21-30.

[4] Aprianto, T dan Purnomo, H. 2014. Desain Pencetak dan Pengepres Tahu pada UKM Tahu Menggunakan Metode Macroergonomic Analysis and Design (MEAD). Seminar Nasional IENACO. ISSN: 2337-4349. 